\title{
Identification and Characterization of Fungi Causing Thread Blight Diseases on Cacao in Ghana
}

\author{
Ishmael Amoako-Attah, ${ }^{1}$ Ali S. Shahin, ${ }^{2}$ M. Catherine Aime, ${ }^{3}$ George T. Odamtten, ${ }^{4}$ Eric Cornelius, ${ }^{5}$ Salome T. Nyaku, \\ E. Kumi-Asare, ${ }^{1}$ Henry B. Yahaya, ${ }^{1}$ and Bryan A. Bailey ${ }^{2, \dagger}$ \\ ${ }^{1}$ Cocoa Research Institute of Ghana, Akim New-Tafo, Ghana \\ ${ }^{2}$ Sustainable Perennial Crops Laboratory, Northeast Area, USDA/ARS, Beltsville Agricultural Research Center-West, Beltsville, \\ MD 20705, U.S.A. \\ ${ }^{3}$ Department of Botany and Plant Pathology, Purdue University, West Lafayette, IN 47907, U.S.A. \\ ${ }^{4}$ Department of Plant and Environmental Biology, University of Ghana, Legon, Ghana \\ ${ }^{5}$ Department of Crop Science, University of Ghana, Legon, Ghana
}

\begin{abstract}
Theobroma cacao (chocolate tree) is currently under serious threat from thread blight disease (TBD), which has been attributed to the causal agent Marasmiellus scandens in other regions of the world. TBD in Ghana has similar symptomology but variable signs. This study sought to determine whether TBD in Ghana was caused by a single agent and whether Marasmiellus scandens was a significant agent of TBD. Forty-eight isolates were collected from eight geographical locations in Ghana for morphological and molecular characterization. Disease signs occurred as vegetative rhizomorphs or hyphal aggregates, which were classified into five morphotypes: A, abundant thin, black, "horse hair"-type rhizomorphs; B, scattered brown rhizomorphs; $\mathrm{C}$, whitish to brownish-white; D, faint cream or dull white; and E, aggregates of shiny or silky white hyphae. Sequencing and analyses

causing TBD-like disease. These were identified as Marasmius crinis-equi (morphotype A), Marasmius tenuissimus (morphotypes B and C), Marasmiellus palmivorus (morphotype E), and Marasmiellus scandens (morphotype D). Marasmius tenuissimus, the most frequently isolated TBD fungus in this study, is primarily an Asian fungus and not previously associated with diseases of cacao. Marasmiellus palmivorus, the second most frequently isolated fungus, is a pan-tropical pathogen with a broad host range; this is the first report of the fungus causing TBD on cacao. Marasmius crinis-equi also has a broad pan-tropical distribution and host range and causes thread blight on several tropical tree crops. Surprisingly, Marasmiellus scandens, the most frequently cited agent of TBD in cacao, made up only $8 \%$ of the isolates.
\end{abstract} of three loci-the internal transcribed spacer region of the nuclear ribosomal repeat, nuclear large subunit, and mitochondrial small subunit-detected four species, all members of the Marasmiaceae,
Keywords: Marasmiaceae, cacao, tropical diseases, rDNA systematics, fungal barcode, thread blight, rhizomorph
Theobroma cacao is the source of cacao beans, the most important raw material for the production of chocolate and other confectionery products enjoyed by millions of people around the world. Diseases are a major constraint to cacao production wherever the crop is cultivated. One disease that is an emerging threat to cacao production in Ghana requiring urgent attention is thread blight disease (TBD) (Amoako-Attah et al. 2016). It is caused by canopy-dwelling basidiomycetous fungi and mostly seen as a network of mycelial "threads" that grow along twigs or branches toward leaves. These threads may be part of the fungal thallus, or they may be specialized vegetative structures formed by aggregates of hyphae with a melanized

${ }^{\dagger}$ Corresponding author: B. A. Bailey; bryan.bailey@ars.usda.gov

Funding: I. Amoako-Attah thanks International Forest Services Program for processing of a travel grant to the USDA/ARS laboratory at Beltsville Agricultural Research Center-West, Beltsville, U.S.A.

References to a company or product are only for the purpose of information and do not imply approval or recommendation of the company or product to the exclusion of others that may also be suitable. USDA is an equal opportunity provider and employer.

*The $\boldsymbol{e}$-Xtra logo stands for "electronic extra" and indicates that supplementary figures are published online.

The author(s) declare no conflict of interest.

Accepted for publication 17 April 2020.

C 2020 The American Phytopathological Society cortex, termed rhizomorphs. The rhizomorphs are important in nutrient exploitation by these fungi (Hedger 1990). When the rhizomorphs contact nutrient-rich substrates, they send out numerous fine hyphae to colonize and initiate necrosis as nutrient uptake commences. This is often seen as distinctive leaf blight symptoms on living hosts. Leaves stop further development when the necrosis starts, and they become dry and detaching from the branch; this ends the pathogenic phase of fungal colonization. When blighted leaves defoliate, they usually remain in the tree canopy through rhizomorph attachment points made prior to leaf abscission (Fig. 1A). The rhizomorphs persist and nutrient uptake continues until advanced stages of decomposition, when defoliated leaves appear papery and their laminas disappear, leaving the veins (Fig. 1B). The fungi, although spending most of their lives as saprobes, are opportunistic pathogens. The fungi do not always grow as rhizomorphs that reach the leaves in the canopy. Instead, they appear as mycelial fans on stem bark and branches that move within the canopy through direct contact with leaves. The main sources of inoculum for TBD infection are leaves or branches carrying fungal mycelia that spread by wind, rain splash, insects, nesting birds, and human activities (César et al. 2018). TBD also spreads from infected parts of tree canopies to the healthy parts of the same tree or the adjoining trees through growth extension of rhizomorphs (Hu 1984). Severe infection often results in a thick mass of dead leaves hanging in the tree canopy, providing a humid environment for pests and other diseases such as Phytophthora pod rot disease to thrive (David 2005).

TBD has a global distribution and is particularly common in humid tropical regions. It is widely distributed in Brazil, the West Indies, and parts of Central America (Barros 1981; Ceresini et al. 
2012; Roberts 1999). Koch and others (2018) reported a similar fungal disease that was killing native plants in Ecuador, Peru, Belize, and Surinam. TBD also occurs on a wide range of crops, and it is reported on cacao trees and other important fruit trees in the upper
Amazon, where cacao is believed to have originated (Gasparotto and Silva 1999). Among important food crops, TBD has been reported on banana, plantain, taro, yam, cocoyam, coconut, maize, and coffee (Dechassa 2019; Nelson and Javier 2001), which also grow
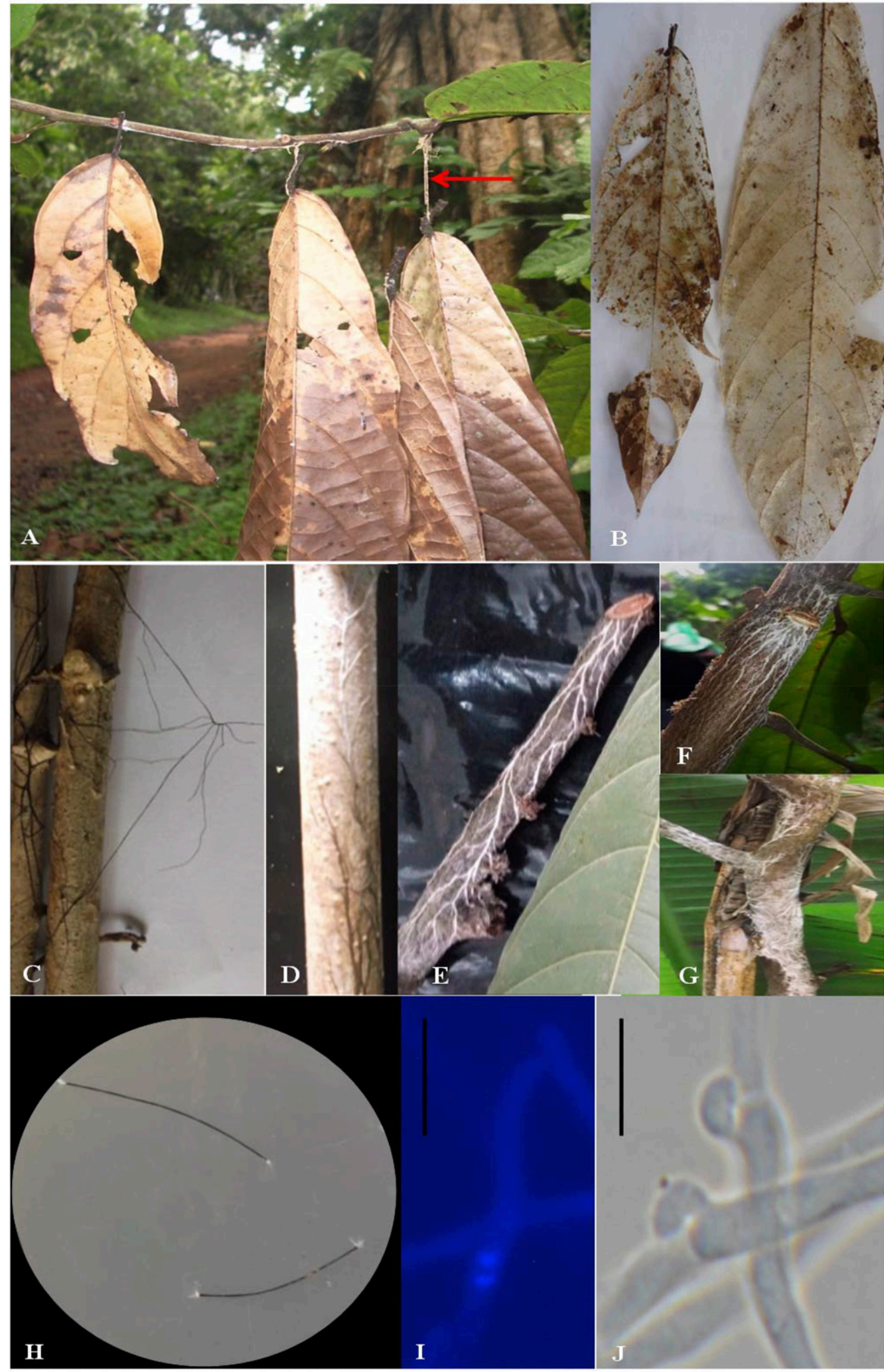

Fig. 1. Thread blight fungi in Ghana: A, rhizomorph (arrow) typically attaching a blighted leaf to a branch; and B, advanced stage of blighted leaves. Rhizomorph colors and growth forms: C, black rhizomorphs; D, brown rhizomorphs; $\mathbf{E}$, white rhizomorphs; F, dull-white rhizomorphs; and $\mathbf{G}$, shiny-white rhizomorphs. $\mathbf{H}$, Hyphae emerging from inside of a black rhizomorph on chloramphenicol water agar at $24 \mathrm{~h}$; I, a binucleate hypha; and J, hyphae with identical clamp connections at the septa junctions. Scale bars: I and J, $50 \mu \mathrm{m}$. 
within the cacao ecosystem. The causal agent of TBD of cacao has been reported as Marasmiellus scandens (Massee) Dennis and Reid (= Marasmius scandens Massee) (Amoako-Attah et al. 2016). In Ghana, several forms of TBD have been reported on cacao and are named according to the color and morphology of the rhizomorphs of the infecting fungi (Lekete 2012; Opoku et al. 2007). What is not known is whether the different morphological forms of TBD reported on cacao in Ghana are caused by the same or other distinct pathogens. Identifying rhizomorph-forming species from their rhizomorphs alone is always problematic. Fungal taxonomy and nomenclature are traditionally dependent on the description of the sexual stage of a fungus: mature fruiting bodies. Because rhizomorphs are sterile vegetative structures, they lack the informative characteristics necessary for positive identification. In this study, 48 fungal isolates causing TBD symptoms were cultured from eight different geographical locations in Ghana. The isolates were sequenced at the fungal barcoding region - the internal transcribed spacer region of the nuclear ribosomal repeat (ITS) (Schoch et al. 2012) - and two other loci. Barcodes of other Marasmiaceae derived from fruiting bodies and other publicly available sequences were used to match the TBD isolates to previously identified species. Finally, we provide descriptions of the signs and symptoms caused by each of the TBDcausing fungi found on cacao in Ghana.

\section{Materials and Methods}

Collections and isolation of TBD fungi. We surveyed 120 cacao plantations in Ghana between March and November of 2017 for TBD samples (Fig. 2). The methods we used for sampling cacao trees and adjacent or interlocking shade crops (e.g., Musa, Cola, and Citrus spp.) were similar to those described under the disease assessment in Amoako-Attah et al. (2016). TBD-infected trees were inspected visually, and the fungal strands consistently associated with the diseases were described and morphologically characterized based on the absence or presence of rhizomorphs, growth form, color, and type of fruiting body. In the laboratory, fruiting body color, size, shape, and features of the pileus, stipe, basidiospores, and their colorations were documented. Fungal isolations were performed using 5- to 10$\mathrm{mm}$ pieces of the rhizomorphs or hyphal strands. These were surface sterilized in $10 \%$ commercial Clorox bleach solution (8.25\% sodium hypochlorite) for $3 \mathrm{~min}$ and washed in three changes of sterile distilled water (SDW), blotted dry on tissue paper, and placed on chloramphenicol water agar plates $(0.01 \mathrm{~g}$ of chloramphenicol, $15 \mathrm{~g}$ of agar powder, 1 liter of SDW) at $28^{\circ} \mathrm{C}$ for $96 \mathrm{~h}$. Sterile inoculating needles were used to transfer single hyphae growing out from the fungal colonies onto oatmeal agar (Difco Laboratories, Franklin Lakes, NJ) prepared according to label instructions. The pure isolates were incubated on the laboratory bench under ambient conditions $\left(26 \pm 2{ }^{\circ} \mathrm{C}\right.$; alternating daylight and night) for adequate growth. We identified the isolates based on morphological characteristics using standard references (Dennis and Reid 1957; Humber 2005; Kirk et al. 2008) as guides, and the cultures were stored in the dark at $18^{\circ} \mathrm{C}$ until needed.

Pathogenicity testing of thread blight isolates. We tested 52 thread blight isolates from eight different cacao-growing locations for their ability to cause TBD symptoms on cacao leaves. The tests were conducted using 3-month-old healthy leaves detached from

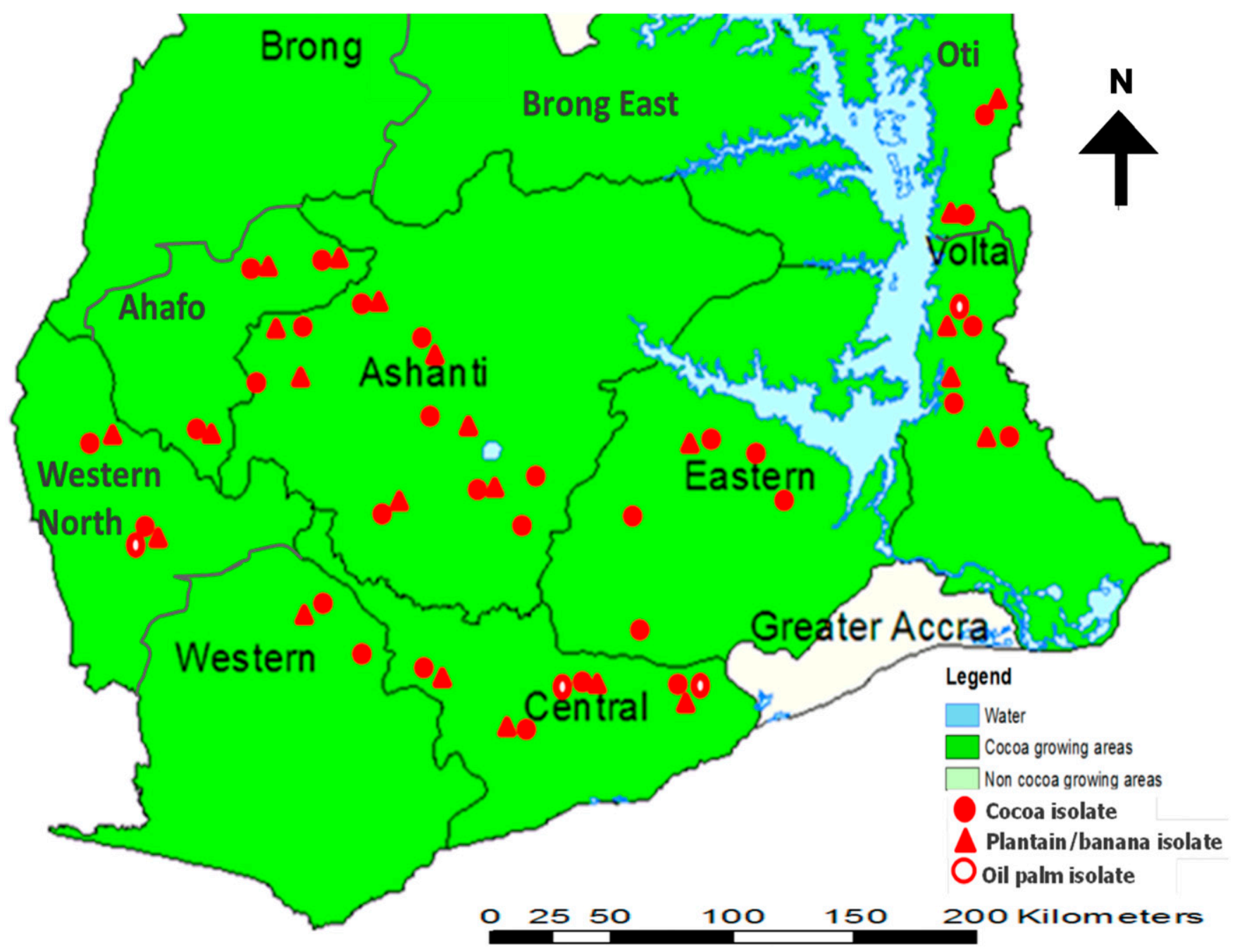

Fig. 2. Geographical locations of thread blight disease samples from different host plants in cacao-growing regions of Ghana. 
mixed hybrid cacao trees in the field. Leaf age was determined by continuously monitoring the growth of young flushes beginning at bud break. A total of 212 leaves were sampled, washed under running water, and rinsed twice in SDW. Then six 10-mm mycelial plugs of a test isolate were placed equidistant on the abaxial leaf surface. Noninoculated leaves served as controls. The leaves were arranged in a completely randomized design, with four replications inside an aluminum tray $(72 \times 62 \times 10 \mathrm{~cm})$ lined with moist plastic foam (latex foam, Ghana Ltd.). Beakers of SDW were placed inside the trays, which were covered and sealed to maintain humidity. We kept the trays on a laboratory bench under ambient conditions $\left(26 \pm 2{ }^{\circ} \mathrm{C}\right.$; alternating daylight and night) and examined them after 7 days for infection and reisolation of the test isolates. The entire experiment was repeated once.

Hyphal characteristics of thread blight isolates. To examine micromorphological features including the nucleus of the isolates, mycelial strands obtained from $20 \%$ clarified V8 juice broth medium were heat fixed onto glass slides and soaked in an ethanol/acetic acid (3:1) solution for $15 \mathrm{~min}$. The slides were air dried and the fungal tissue stained with 4', 6-diamidino-2-phenylindole (Life Technologies, Carlsbad, CA) and observed with a Nikon Eclipse E600 fluorescent microscope (Nikon, Melville, NY) mounted with a Nikon digital camera (DXM1200).

DNA extraction from thread blight isolates. We performed DNA extraction on 48 pathogenic isolates grown in $20 \%$ clarified V8 juice broth. After 7 days, the mycelia were washed with SDW and harvested under suction pressure by passing them through a Büchner funnel lined with Mira cloth. Approximately 0.5-g mycelia samples were ground in liquid nitrogen and the fine powder added to $10 \mathrm{ml}$ of prewarmed $\left(65^{\circ} \mathrm{C}\right)$ modified cetyltrimethylammonium bromide (CTAB) buffer (3\% CTAB, $100 \mathrm{mM}$ Tris, $\mathrm{pH}$ 8, 20 mM EDTA, $\mathrm{pH} 8,1.4 \mathrm{M} \mathrm{NaCl}, 1 \%$ PVP 40,000, $200 \mu \mathrm{l}$ of 2-mercaptoethanol, and $2 \mu \mathrm{g} / \mathrm{ml}$ of $10 \%$ proteinase $\mathrm{K}$ ) in a 50 -ml Oakridge tube (Nalgene, Rochester, NY). The tube was then incubated at $65^{\circ} \mathrm{C}$ for 1 $\mathrm{h}, 10 \mathrm{ml}$ of chloroform added, mixed gently, and centrifuged at $12,000 \mathrm{rpm}$ for $30 \mathrm{~min}$. The upper phase was added to $10 \mathrm{ml}$ of chloroform and centrifuged again for 20 min to collect the upper phase containing DNA. The DNA was precipitated by adding $5 \mathrm{ml}$ of $7.5 \mathrm{M}$ ammonium acetate and $20 \mathrm{ml}$ of absolute alcohol, kept on ice for $1 \mathrm{~h}$, and then centrifuged at 12,000 rpm for $30 \mathrm{~min}$. DNA pellets were washed with $5 \mathrm{ml}$ of chilled ethanol (70\%) by centrifuging at $12,000 \mathrm{rpm}$ for $10 \mathrm{~min}$ and then air dried. The pellets were resuspended in $500 \mu \mathrm{l}$ of Milli-Q water and treated with $10 \mu \mathrm{l}$ of RNase A (Invitrogen, Carlsbad, CA) enzyme before incubation at $37^{\circ} \mathrm{C}$ for $30 \mathrm{~min}$. Chloroform $(500 \mu \mathrm{l})$ was added, mixed gently, and centrifuged at $12,000 \mathrm{rpm}$ for $10 \mathrm{~min}$ to collect the upper DNA phase. DNA was precipitated $(250 \mu \mathrm{l}$ of $7.5 \mathrm{M}$ ammonium acetate and $1 \mathrm{ml}$ of absolute alcohol) and the DNA pellets washed and dried as previously described.

Polymerase chain reaction (PCR) amplification and DNA sequencing of ITS, mitochondrial small subunit ribosomal RNA (mtSSU rRNA), and nuclear large ribosomal subunit (LSU) regions. We amplified the entire ITS region and $5^{\prime}$ region of the mtSSU rDNA using primers ITS4 (5'-TCCTCCGCTTATTGATATGC) and ITS5 (5'-GGAAGTAAAAGTCGTAACAAGG) and MS1 (5'-CAGCAGTCAAGAATATTAGTCAATG) and MS2 (5'-GCGGATTATCGAAT TAAATAAC), respectively (White et al. 1990). Additionally, the first $1,250 \mathrm{bp}$ of the nuclear LSU of the template DNA was amplified for 10 isolates with primers described by Aime and Phillips-Mora (2005). PCR was performed in 25- $\mu$ l reaction volumes made up of $1 \mu \mathrm{l}$ of genomic DNA, $0.5 \mu \mathrm{l}$ each of $10 \mu \mathrm{M}$ primer pair, $2.5 \mu \mathrm{l}$ of $10 \times \mathrm{PCR}$ buffer, $0.75 \mu l$ of $50 \mathrm{mM}$ magnesium chloride $\left(\mathrm{MgCl}_{2}\right), 0.5 \mu \mathrm{l}$ $10 \mathrm{mM}$ deoxynucleoside-triphosphate (dNTP) mix, $0.1 \mu$ l Platinum Taq DNA polymerase (Invitrogen), and SDW to complete the final volume. Amplification was carried out in a Gene Amp 9700 Thermal Cycler. The cycling conditions were as follows: an initial denaturation step at $95^{\circ} \mathrm{C}$ for $2 \mathrm{~min}$; followed by 30 cycles, each consisting of $95^{\circ} \mathrm{C}$ for $30 \mathrm{~s}$ denaturing, annealing at $52^{\circ} \mathrm{C}$ for $30 \mathrm{~s}$, and $72^{\circ} \mathrm{C}$ for $45 \mathrm{~s}$; with a final extension at $72^{\circ} \mathrm{C}$ for $5 \mathrm{~min}$. For the $\mathrm{mtSSU}$ and LSU, however, the annealing temperatures were set at 54 and $50^{\circ} \mathrm{C}$, respectively, for
30 s. We cleaned the PCR products with an ExoSAP-IT Express (Life Technologies) following the manufacturer's instructions, and the final product was sent to Macrogen (Rockville, MD) for sequencing in both directions. Ambiguous sites were edited manually using Sequencher version 5.2.3 software (Gene Codes, Ann Arbor, MI), and sequences were exported for phylogenetic analysis. The complete DNA sequences used in the study were deposited in the GenBank with the accessions MN794066 to MN794185 (Table 1).

Phylogenetic analysis. The edited sequences were initially subjected to BLASTn search against the National Center for Biotechnology Information (NCBI) database (https://www.ncbi.nlm.nih.gov) to obtain a tentative identification. Our 48 sequenced isolates were assigned to the Marasmiaceae using this method, and they were selected for additional sequencing analyses. Initially, the sequences were aligned and analyzed within a dataset of ITS sequences for 615 Marasmiaceae (Aime, unpublished). A second dataset was constructed of (i) exemplar taxa representing all sister lineages to the TBD fungi as identified in the preliminary analysis and (ii) exemplars from each genus of Marasmiaceae (Aime and Phillips-Mora 2005; Koch et al. 2018) (Table 2). These were aligned in Geneious 9.1.5 (Biomatters, Auckland, NZ) using the MUSCLE algorithm (Edgar 2004). Individual alignments were then concatenated in Geneious and analyzed by maximum likelihood (RAxML; Stamatakis 2014) methods using the CIPRES Science Gateway (Miller et al. 2010), following the methods of Koch et al. (2018). Single-locus trees for LSU and mtSSU were constructed and analyzed in MAAFT version 7 (Katoh and Standley 2013) with refinements to the alignment done manually. Maximum likelihood bootstrap analysis for phylogeny and assessment of the branch support by bootstrap percentages was performed using RAxML version 8 (Stamatakis 2014). One thousand bootstrap replicates were produced.

\section{Results}

Morphological description. Vegetative structures of TBDcausing fungi were classified within distinct morphotypes: A (black), B (brown), C (whitish to brownish-white), D (faint cream or dull white), and $\mathrm{E}$ (shiny or silky white) (Table 1, Fig. 1C to G). The fungus in morphotype A occurred in the field as smooth, wiry, black rhizomorphs attached to the hosts by small dark pads (byssi) at certain points along the strands. The rhizomorphs could be pulled easily at their free ends (Fig. 1C). It was observed that the fungus did not grow in any particular direction, but the tough rhizomorphs entangled the host foliage, and most defoliated leaves were trapped within the fungal web. Leaf blight symptoms characteristic of TBD were rare on trees infected with morphotype A, but affected trees were heavily defoliated. Fructification of the morphotype A fungus was not encountered in the field. Isolates of morphotype A were more frequently associated with cacao and cola nut trees and were found in the Ashanti and Eastern regions of Ghana (Table 1).

Morphotype B fungus occurred in the field as brown to darkbrown rhizomorphs attached closely to the host along their entire length. Initial growth of this fungus on hosts was white but became brown with maturity (Fig. 1D). The fungus grew mostly toward leaves of affected branches, where the brown to dark-brown rhizomorphs produced very fine white hyphae that infected the leaf. Morphotype B was found commonly in Central, Eastern, and Western regions of Ghana on cacao trees and occasionally on food crops, including cassava (Manihot esculenta). Fructification of morphotype B was never encountered in the field.

For morphotype $\mathrm{C}$, with the exception of rhizomorph color, all other characteristics were similar to those of morphotype B described above. Morphotype $\mathrm{C}$ occurred as white rhizomorphs on branches, twigs, and leaves (Fig. 1E), but at the advanced stages of their growth the rhizomorphs appeared cream colored (buff or beige). Morphotype $\mathrm{C}$ was identified in all the cacao growing regions of Ghana and occurred on cacao as well as other crops (Table 1). This morphotype constituted more than half $(53.4 \%)$ of the fungi recovered in the study.

Morphotype D usually appeared as a dull-white (faint cream) mass of cottony mycelium on host plants (e.g., cacao and plantain/banana) 
with a poorly defined thread-like growth pattern (Fig. 1F). It generally produced mycelial fans that were not seen growing onto the host leaves but remained on branches and twigs, causing dieback symptoms. Where cacao leaves came into direct contact with infected twigs or branches, the fungus attacked and caused leaf blight symptoms. In the few cases where the fungus also formed rhizomorphs, it grew over the leaf petioles and infected the leaf. On occasion, fructification of morphotype D was observed in the field as small, almost adpressed powdery-cream mushrooms arising directly from whitish to light cream rhizomorphs at irregular intervals on leaves or twigs (Fig. 3). These were detected at the end of the rainy season in October, in a high-humidity environment. The pileus was smooth, creampruinose, orbicular to slightly reniform, and of varying diameters up to $8 \mathrm{~mm}$. The stipe was short, 0.5 to $1 \mathrm{~mm}$ in length, insititious, curved, cylindrical, and brown. It was almost laterally positioned and extended the pileus so that it seemed adpressed to the host substrate (Fig. 3). The hymenium was yellowish, becoming brown on drying with two to five diverging gill-like folds emerging from the stipe, exhibiting a fork-shape appearance and hyaline hyphal margin. Scant hyaline, oval to elliptical, and apiculate basidiospores 7 to $8 \times 3$ to $5.2 \mu \mathrm{m}$ were produced (Fig. 3B). Morphotype D fungi were more commonly encountered in the Central and Volta regions of Ghana.

Morphotype E fungus grew as a thick cottony aggregation of shiny (silky) white mycelium without any rhizomorph formation on host surfaces (Fig. 1G). Morphotype E fungi seldom grew onto leaves of affected twigs or branches but caused dieback and leaf blight symptoms just like morphotype D. Fructification of morphotype E (Fig. 4) was seen as white to pale yellow basidiocarps, commonly

Table 1. Fungal isolates causing thread blight disease of cacao in Ghana

\begin{tabular}{|c|c|c|c|c|c|c|c|c|}
\hline \multirow[b]{2}{*}{ Isolate } & \multirow[b]{2}{*}{ Putative species identification } & \multirow[b]{2}{*}{ Morphotype } & \multirow[b]{2}{*}{ Geographic location ${ }^{a}$} & \multirow[b]{2}{*}{ Year of isolation } & \multirow[b]{2}{*}{ Host plant } & \multicolumn{3}{|c|}{ GenBank accession number } \\
\hline & & & & & & ITS $^{\mathbf{b}}$ & mtSSU $^{b}$ & LSU $^{\mathbf{b}}$ \\
\hline GH-6 & Marasmius tenuissimus & $\mathrm{C}$ & Eastern & 2017 & Cacao/plantain & MN794161 & MN794106 & \\
\hline GH-7 & Marasmius tenuissimus & $\mathrm{C}$ & Ashanti & 2017 & Cacao & MN794171 & MN794115 & \\
\hline GH-8 & Marasmius tenuissimus & $\mathrm{C}$ & Ashanti & 2017 & Cacao & MN794178 & MN794122 & \\
\hline GH-9 & Marasmius tenuissimus & $\mathrm{C}$ & Ashanti & 2017 & Cacao & MN794181 & MN794125 & \\
\hline GH-10 & Marasmiellus palmivorus & $\mathrm{E}$ & Ahafo & 2017 & Cacao/plantain & MN794130 & MN794075 & \\
\hline GH-11 & Marasmiellus palmivorus & $\mathrm{E}$ & Ahafo & 2017 & Cacao/plantain & MN794131 & MN794076 & MN794066 \\
\hline GH-12 & Marasmiellus palmivorus & $\mathrm{E}$ & Ahafo & 2017 & Cacao/plantain & MN794132 & MN794077 & \\
\hline GH-13 & Marasmius tenuissimus & $\mathrm{C}$ & Western/W-North & 2017 & Cacao/oil palm & MN794133 & MN794078 & \\
\hline GH-14 & Marasmius tenuissimus & $\mathrm{C}$ & Western/W-North & 2017 & Cacao & MN794134 & MN794079 & \\
\hline GH-16 & Marasmiellus scandens & $\mathrm{D}$ & Central & 2017 & Cacao/plantain & MN794135 & MN794080 & \\
\hline GH-17 & Marasmiellus scandens & $\mathrm{D}$ & Central & 2017 & Cacao/plantain & MN794136 & MN794081 & MN794067 \\
\hline GH-18 & Marasmiellus scandens & $\mathrm{D}$ & Central & 2017 & Cacao/plantain & MN794137 & MN794082 & \\
\hline GH-19 & Marasmiellus scandens & $\mathrm{D}$ & Volta & 2017 & Citrus/plantain & MN794138 & MN794083 & \\
\hline GH-27 & Marasmiellus palmivorus & $\mathrm{E}$ & Western/W-North & 2017 & Cacao/plantain & MN794141 & MN794086 & \\
\hline GH-32 & Marasmius tenuissimus & $\mathrm{C}$ & Eastern & 2017 & Cacao & MN794142 & MN794087 & \\
\hline GH-35 & Marasmius tenuissimus & $\mathrm{C}$ & Eastern & 2017 & Cacao & MN794145 & MN794090 & \\
\hline GH-36 & Marasmius crinis-equi & $\mathrm{A}$ & Eastern & 2016 & Cacao & MN794146 & MN794091 & \\
\hline GH-37 & Marasmius tenuissimus & $\mathrm{C}$ & Eastern & 2017 & Cacao & MN794147 & MN794092 & \\
\hline GH-38 & Marasmius tenuissimus & $\mathrm{B}$ & Eastern & 2017 & Cacao & MN794148 & MN794093 & \\
\hline GH-40 & Marasmius tenuissimus & $\mathrm{C}$ & Eastern & 2017 & Cacao/kola & MN794149 & MN794094 & \\
\hline GH-41 & Marasmius tenuissimus & $\mathrm{C}$ & Ashanti & 2017 & Cacao & MN794150 & MN794095 & \\
\hline GH-42 & Marasmius tenuissimus & $\mathrm{C}$ & Ashanti & 2017 & Cacao & MN794151 & MN794096 & \\
\hline GH-46 & Marasmius crinis-equi & A & Ashanti & 2017 & Cacao & MN794152 & MN794097 & MN794069 \\
\hline GH-47 & Marasmius tenuissimus & $\mathrm{C}$ & Ashanti & 2017 & Cacao & MN794153 & MN794098 & \\
\hline GH-49 & Marasmius tenuissimus & $\mathrm{C}$ & Ahafo & 2017 & Cacao & MN794154 & MN794099 & \\
\hline GH-54 & Marasmius tenuissimus & $\mathrm{C}$ & Ahafo & 2017 & Cacao & MN794157 & MN794102 & \\
\hline GH-56 & Marasmius tenuissimus & $\mathrm{C}$ & Western/W-North & 2017 & Cacao & MN794158 & MN794103 & \\
\hline GH-57 & Marasmius tenuissimus & $\mathrm{C}$ & Western/W-North & 2017 & Cacao & MN794159 & MN794104 & \\
\hline GH-59 & Marasmius tenuissimus & $\mathrm{B}$ & Western/W-North & 2017 & Cacao & MN794160 & MN794105 & \\
\hline GH-60 & Marasmius tenuissimus & $\mathrm{C}$ & Western/W-North & 2017 & Cacao & MN794162 & MN794107 & \\
\hline GH-61 & Marasmius tenuissimus & $\mathrm{C}$ & Western/W-North & 2017 & Cacao & MN794163 & MN794108 & \\
\hline GH-62 & Marasmius tenuissimus & $\mathrm{C}$ & Central & 2017 & Cacao & MN794164 & MN794109 & \\
\hline GH-63 & Marasmius tenuissimus & $\mathrm{C}$ & Central & 2017 & Cacao & MN794165 & MN794110 & MN794071 \\
\hline GH-64 & Marasmius tenuissimus & B & Central & 2017 & Cacao & MN794166 & MN794111 & \\
\hline GH-65 & Marasmius tenuissimus & $\mathrm{C}$ & Central & 2017 & Cacao & MN794167 & MN794112 & \\
\hline GH-67 & Marasmius tenuissimus & $\mathrm{C}$ & Central & 2017 & Cacao & MN794169 & MN794114 & \\
\hline GH-70 & Marasmius tenuissimus & $\mathrm{C}$ & Volta & 2017 & Cacao & MN794172 & MN794116 & \\
\hline GH-74 & Marasmius tenuissimus & $\mathrm{C}$ & Volta & 2017 & Cacao & MN794173 & MN794117 & \\
\hline GH-76 & Marasmius crinis-equi & A & Ashanti & 2017 & Cacao & MN794174 & MN794118 & MN794072 \\
\hline GH-77 & Marasmius crinis-equi & A & Ashanti & 2017 & Cacao/kola & MN794175 & MN794119 & \\
\hline GH-78 & Marasmius tenuissimus & $\mathrm{B}$ & Eastern & 2017 & Cacao & MN794176 & MN794120 & \\
\hline GH-79 & Marasmius tenuissimus & $\mathrm{B}$ & Eastern & 2017 & Cacao & MN794177 & MN794121 & MN794073 \\
\hline GH-80 & Marasmiellus scandens & $\mathrm{D}$ & Volta & 2017 & Cacao & MN794179 & MN794123 & \\
\hline GH-81 & Marasmiellus palmivorus & $\mathrm{E}$ & Volta & 2017 & Cacao & MN794180 & MN794124 & \\
\hline MS-1 & Marasmius tenuissimus & $\mathrm{C}$ & Eastern & 2016 & Cacao & MN794182 & MN794126 & \\
\hline MS-2 & Marasmius tenuissimus & $\mathrm{C}$ & Eastern & 2016 & Cacao & MN794183 & MN794127 & MN794074 \\
\hline MS-3 & Marasmius tenuissimus & $\mathrm{C}$ & Eastern & 2016 & Cacao & MN794184 & MN794128 & \\
\hline MS-4 & Marasmius tenuissimus & $\mathrm{C}$ & Eastern & 2016 & Cacao & MN794185 & MN794129 & \\
\hline
\end{tabular}

a W-North = Western North.

${ }^{\mathrm{b}}$ ITS = rDNA internal transcribed spacer region; $\mathrm{mtSSU}=$ mitochondrial small subunit region; and LSU = nuclear large subunit region. 
Table 2. Sequences of Marasmiaceae isolates used in the study

\begin{tabular}{|c|c|c|c|c|c|}
\hline \multirow[b]{2}{*}{ Name } & \multirow[b]{2}{*}{ Specimen IDa } & \multirow[b]{2}{*}{ Origin } & \multicolumn{3}{|c|}{ Accession number } \\
\hline & & & ITS $^{\mathbf{b}}$ & $\mathbf{m t S S U}^{\mathbf{b}}$ & $\mathbf{L S U}^{\mathbf{b}}$ \\
\hline Brunneocorticium sp. & MCA 5803 & Guyana & MG717360c & MG717336c & MG717348c \\
\hline Brunneocorticium sp. & MCA 6199 & Guyana & MG717362 & & \\
\hline Campanella olivaceonigra (Horak) May \& Wood & AQ 793973 & Australia & JX444167 & & \\
\hline Campanella pustulata (Berk \& Broome) Lloyd & SMF 2382 & Australia & JX444164 & & \\
\hline Chaetocalathus liliputianus (Mont.) Singer & MCA 485 & Puerto Rico & AY916682d & AY916681 & AY916680 d \\
\hline Chaetocalathus liliputianus & C 61867 & Ecuador & AY571032 & & AY570996 \\
\hline Crinipellis sp. & MCA 1527 & Guyana & AY916701d & AY916700d & AY916699d \\
\hline Crinipellis sp. & MCA 2240 & Guyana & MG717367c & & AY916695 d \\
\hline Marasmius brunneoaurantiacus Antonín \& Buyck & JES 133 (SFSU) & Madagascar & KX149009e & & \\
\hline Marasmius crinis-equi & NW 348 & Thailand & EU935555 & & EU935555 \\
\hline Marasmius guyanensis (Mont.) & NW 254 & Thailand & EU935552 & & \\
\hline Marasmius guyanensis (Mont.) & NW 280 & Thailand & EU935553 & & \\
\hline Marasmius madagascariensis Shay \& Desjardin & JES 139 (SFSU) & Madagascar & NR $158834^{\mathrm{e}}$ & & \\
\hline Marasmiellus palmivorus & VPCI 455/P/12 & India & KF291013 & & \\
\hline Marasmiellus palmivorus & MPOB 1 & Malaysia & JQ653435 f & & \\
\hline Marasmiellus palmivorus & UPM 4 & Malaysia & & & JQ654217 f \\
\hline Marasmiellus palmivorus & BPSM 38 & India & KM985675 & & \\
\hline Marasmiellus palmivorus & C 1 & Malaysia & JQ653443 & & \\
\hline Marasmiellus palmivorus & M 121 & Philippines & KR056290 & & \\
\hline Marasmiellus palmivorus & LA 1 & India & KP125487 & & \\
\hline Marasmiellus palmivorus & UPM 3 & Malaysia & JQ653430 f & & \\
\hline Marasmiellus palmivorus & Bangi 6 & Malaysia & $\mathrm{JQ653437^{ \textrm {f } }}$ & & JQ654226 \\
\hline Marasmiellus palmivorus & M 133 & Philippines & KR056289 & & \\
\hline Marasmiellus palmivorus & OP 2 & Malaysia & JQ653429f & & JQ654220f \\
\hline Marasmiellus palmivorus & NO 5 & Malaysia & JQ653426f & & JQ654230f \\
\hline Marasmiellus palmivorus & Bangi & Malaysia & JQ653427 & & JQ654223 ${ }^{\mathrm{f}}$ \\
\hline Marasmiellus palmivorus & UPM 2 & Malaysia & JQ653432f & & JQ654214 \\
\hline Marasmiellus palmivorus & EGBE 9 & Nigeria & KT273356 & & \\
\hline Marasmiellus palmivorus & UPM 32 & Malaysia & JQ653428f & & JQ654216 f \\
\hline Marasmiellus palmivorus & OP 4 & Malaysia & JQ653424f & & JQ654221 ${ }^{\mathrm{f}}$ \\
\hline Marasmiellus palmivorus & Bangi 3 & Malaysia & JQ653433 ${ }^{\mathrm{f}}$ & & JQ654224f \\
\hline Marasmiellus palmivorus & PK-27 & India & KC771224 & & \\
\hline Marasmiellus palmivorus & Bangi 7 & Malaysia & JQ653438f & & JQ654227f \\
\hline Marasmiellus palmivorus & KUBOTSCHD 6 & India & & KX290489 & \\
\hline Marasmiellus sp. & AR 810 & Indonesia & JQ586344 & & \\
\hline Marasmiellus sp. & AR 809 & Indonesia & JQ586345 & & \\
\hline Marasmiellus sp. & MEL 2382677 & Australia & KP013040 & & \\
\hline Marasmiellus sp. & FLAS-F-60876 & USA & MH016862 & & \\
\hline Marasmiellus sp. & AKD 208/2014 & India & MF189077 & & \\
\hline Marasmius palmivorus & SFSU:BAP 641 & Sao Tome & & MF100969 & \\
\hline Marasmius palmivorus & SFSU:DED 8219 & Sao Tome & & MF100966 & \\
\hline Marasmius palmivorus & SFSU:DED 8337 & Sao Tome & & MF100967 & \\
\hline Marasmius palmivorus & SFSU:BAP 625 & Sao Tome & & MF100965 & \\
\hline Marasmius palmivorus & SFSU:BAP 628 & Sao Tome & & & MF100964 \\
\hline Marasmius palmivorus & AKD 112/2015 & India & & MG251431 & MG251441 \\
\hline Marasmius palmivorus & BPSM 03 & & KJ865833 & & \\
\hline Marasmius palmivorus & $\mathrm{JZ} 7$ & India & MG437335 & & \\
\hline Marasmius palmivorus & HB 16 & Philippines & & MF377432 & \\
\hline Marasmius palmivorus & SFSU:DED 8281 & Principe & & MF100968 & \\
\hline
\end{tabular}

a Identities and sources of Marasmiaceae sequences used in the study. Author collections: MCA = Mary Catherine Aime, Purdue University; SMF = Sapphire McMullan-Fisher, Royal Botanic Gardens, Australia; NW = Nopparat Wannathes, Chiang Mai University, Thailand; PK = Pandiyan Kuppusamy, Indian Agricultural Research Institute; KUBOTSCHD = Sujata Chaudhuri and Hemanta Kumar Datta, Department of Botany, University of Kalyani; AR = Atik Retnowati, Indonesian Institute of Sciences; AKD = Arun Kumar Dutta, University of Calcutta, Kolkata; BBKAV = Basappa Basawanneppa Kaliwal and Adiveppa Vantamuri Bheemappa, Karnatak University; BPSM = Bhim Pratap Singh, Mizoram University, Aizawl; JZ = John Zothanzama, Mizoram University, Aizawl; TYS = Tan Yee Shin, University of Malaya, Malaysia; JES = Jacqueline Elizabeth Shay, San Francisco State University (SFSU); BAP = Brian A. Perry (SFSU); and DED = Dennis E. Desjardin (SFSU). Herbarium and culture collections: VPCI = Vallabhbhai Patel Chest Institute, New Delhi; UPM = Universiti Putra Malaysia; BRMN = Herbarium of the Moravian Museum, Brno, Czech Republic; SCAU = South China Agricultural University, Guangdong; TENN = University of Tennessee. Locations of collections: MEL = Melbourne, Australia; AQ = Queensland, Australia; Bangi = Bangi, Selangor; MPOB = Malaysian Palm Oil Board; EGBE = Egbelu, River State, Nigeria; NO = Negeri Sembilan, Oilpalm, Malaysia; HB = Barangays of Hapao, Ifugao, Philippines and FLAS-F = Sabal palm tree at Lake Alice, Florida. Type of isolation: $\mathrm{C}=$ coconut isolate; $\mathrm{OP}=$ oil palm isolate; $\mathrm{M}=$ Marasmius isolate; and LA $=$ laccase producer.

$\mathrm{b}$ ITS = rDNA internal transcribed spacer region; $\mathrm{mtSSU}=$ mitochondrial small subunit region; and LSU = nuclear large subunit region.

c Koch et al. (2018)

d Aime and Phillips-Mora (2005).

e Shay (2016).

f Al-Maliky et al. (2012) (available online at https://blast.ncbi.nlm.nih.gov/Blast.cgi)

g Vantamuri and Kaliwal (2015). 
on cacao stems during the rainy season, but most frequently on pseudo stems of plantain or banana. The pileus was smooth, convex of 10 to $50 \mathrm{~mm}$ in diameter, slightly depressed at the center, with involute margins. When young, the pilei were white, becoming light orange at maturity with thin, white, membranous context. The stipe was shiny white with an orange base, cylindrical, 15 to $60 \mathrm{~mm}$, central to the pileus, and possessed adnate lamellae. Numerous hyaline, elliptical spores 8.7 to $9 \times 6$ to $6.2 \mu \mathrm{m}$ were produced. Morphotype $\mathrm{E}$ occurred most often in the Ahafo and Volta regions of Ghana.

In culture, the isolates grew out from inside of the fungal tissue or rhizomorph (Fig. 1H), and pure cultures of the different morphotypes produced colonies that were initially silky or cottony white but later developed colony colors reflecting the field colorations of the rhizomorph or mycelial strands (Supplementary Fig. S1). Cultures of morphotype A were white but darkened from the early stages of their growth, whereas morphotype B became entirely brown after 21 days of incubation. During this same period, the mycelial mat of morphotype $\mathrm{C}$ became pale brownish-white. Colonies of morphotype D isolates developed dull-white mycelial mats and remained so throughout the growth period. Morphotype E isolates formed pinkish mycelial mats in culture, but this was at the advanced stage of 28 days after inoculation. Isolates from morphotypes $\mathrm{B}$ and $\mathrm{C}$ grew moderately, whereas isolates of morphotypes $\mathrm{D}$ and $\mathrm{E}$ grew rapidly. Morphotype A produced a slow-growing mycelium in culture. Microscopically, all the fungal isolates produced hyaline, dikaryotic hyphae with numerous clamp connections (Fig. 1I). Clamp connections were identical across morphotypes, and septa occurred at the clamped junction (Fig. 1J). These observations were similar to those described by Singer (1976) for Marasmiaceae species.

Pathogenicity test. Out of the 52 TBD isolates tested, 48 were able to grow on cacao leaves and initiated necrosis similar to that observed in the field. Pathogenicity was confirmed when the fungal isolates were reisolated from leaves with symptoms similar to those found in the field. Noninoculated (control) cacao leaves remained healthy and showed no symptoms of necrosis.

Phylogenetic analyses. Based on the initial BLASTn search against the NCBI database and some preliminary phylogenetic analyses, $48 \mathrm{ITS}, 48 \mathrm{mtSSU}$, and six LSU sequences were predicted to be Marasmiaceae-related and suggested further studies (Table 1). ITS fragment sizes were from 457 to $609 \mathrm{bp}$, mtSSU from 517 to $565 \mathrm{bp}$, and the LSU sequences from 948 to $996 \mathrm{bp}$. Both the ITS and $\mathrm{mtSSU}$ phylogenetic trees grouped the $48 \mathrm{TBD}$ fungi examined into four distinct branches that were supported statistically (Supplementary Fig. S2). The ITS- and mtSSU-based groupings, in general, corresponded to morphotypes A, B, D, and E identifications based on morphology. There was a minor sequence variation within the B and $\mathrm{C}$ morphotypes that, for the ITS sequence, separated morphotype $\mathrm{C}$ into two groups and further separated morphotype $\mathrm{C}$ from morphotype B isolates other than GH-79. The mtSSU sequence analysis placed morphotypes $\mathrm{B}$ and $\mathrm{C}$ in the same phylogenetic group with the only exception again being isolate GH-79 (Supplementary Fig. S2A to B). To further strengthen the identity of the morphotypes, the LSU sequences of six isolates were also analyzed with results similar to the ITS- and mtSSU-based analyses (Supplementary Fig $\mathrm{S} 2 \mathrm{C}$ ). As there was little publicly available sequence information for mtSSU and LSU, a final phylogenetic analysis of all 48 TBD isolates was performed using ITS sequences. For the analysis, ITS sequences of Marasmiaceae from published sources and herbarium materials were used as references and outgroups (Table 2) along with the 48 TBD isolates. Morphotype A was identified as Marasmius crinis-equi F. Muell. ex Kalchbr; morphotypes B and C were identified as a single species, Marasmius tenuissimus (Sacc.) Singer; and morphotypes D and E were identified as Marasmiellus scandens (Massee) Dennis \& Reid and Marasmiellus palmivorus (Sharples) Desjardin, respectively (Fig. 5).

\section{Discussion}

TBD is currently considered one of the most important foliar diseases on cacao (chocolate) trees in Ghana (Amoako-Attah et al.
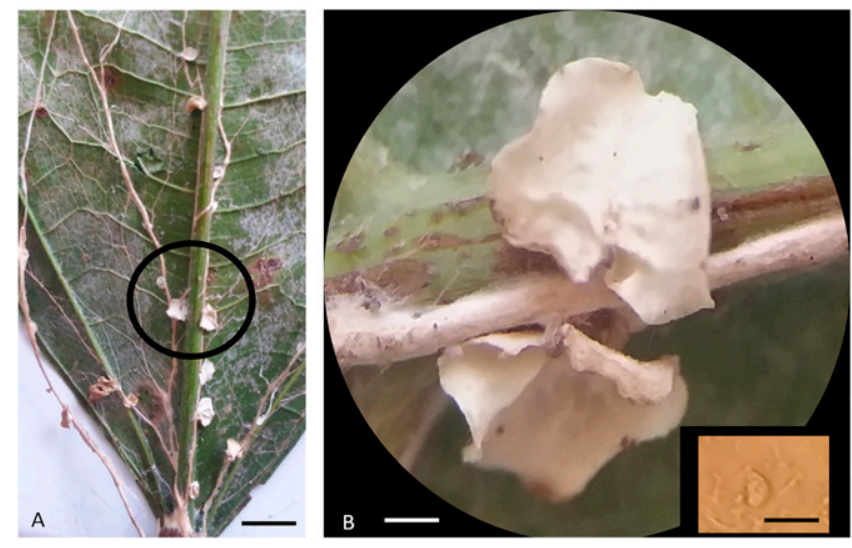

Fig. 3. Fructification of Marasmiellus scandens (morphotype D): A, basidiocarps on a cacao leaf; and B, close-up of basidiocarps and an apiculate basidiospore (insert). Scale bars, $2 \mathrm{~mm}$ (insert $=5 \mu \mathrm{m}$ ).

Table 2. (Continued from previous page)

\begin{tabular}{|c|c|c|c|c|c|}
\hline \multirow[b]{2}{*}{ Name } & \multirow[b]{2}{*}{ Specimen ID } & \multirow[b]{2}{*}{ Origin } & \multicolumn{3}{|c|}{ Accession number } \\
\hline & & & ITS $^{\mathbf{b}}$ & $\operatorname{mtSSU}^{\mathbf{b}}$ & $\mathbf{L S U}^{\mathbf{b}}$ \\
\hline Marasmius palmivorus & BPSM 13 & India & KJ865843 & & \\
\hline Marasmius ruforotula Singer & BRMN 714674 & Korea Republic & FJ936150 & & FJ917612 \\
\hline Marasmius sp. & BBKAV 79 & India & KP455496g & & KP455497g \\
\hline Marasmius sp. & JES 225 (SFSU) & Madagascar & KX149006 & & \\
\hline Marasmius sp. & JES 139 (SFSU) & Madagascar & KX149015 & & \\
\hline Marasmius tenuissimus & NW 199 & Thailand & EU935569 & & \\
\hline Marasmius tenuissimus & AKD 304/2015 & India & MF189066 & & MF189066 \\
\hline Marasmius tenuissimus & SCAU 111 & China & MF061773 & & MF061773 \\
\hline Marasmius tenuissimus & NW 192 & Thailand & EU935568 & & \\
\hline Marasmius tenuissimus & $\mathrm{C} 2 / 06$ & Brazil & KM246261 & & KM246066 \\
\hline Marasmius tenuissimus & $\mathrm{C} 2 / 33$ & Brazil & KM246277 & & KM246082 \\
\hline $\begin{array}{l}\text { Moniliophthora roreri (Cif.) H.C. Evans, Stalpers, } \\
\text { Samson \& Benny }\end{array}$ & MCA 2521 & Ecuador & & & AY916750 \\
\hline Moniliophthora roreri & MCA 2953 & Mexico & & DQ222925 & DQ222926 \\
\hline Moniliophthora roreri & MCA 2952 & Mexico & DQ222923 & & DQ222924 \\
\hline Moniliophthora sp. & MCA 2500 & USA & AY916754 & AY916753 & AY916752d \\
\hline Tetrapyrgos nigripes (Fr.) E. Horak & TENN 60065 & USA & KT270853 & & \\
\hline $\begin{array}{l}\text { Tetrapyrgos subcinerea (Berk. \& Broome) E. } \\
\text { Horak }\end{array}$ & TYS 347 & USA & KT270857 & & \\
\hline
\end{tabular}


2016). In this study, five distinct fungal morphotypes were consistently associated with TBD in cacao plantations causing black thread blight (morphotype A), brown thread blight (morphotype B), pure-
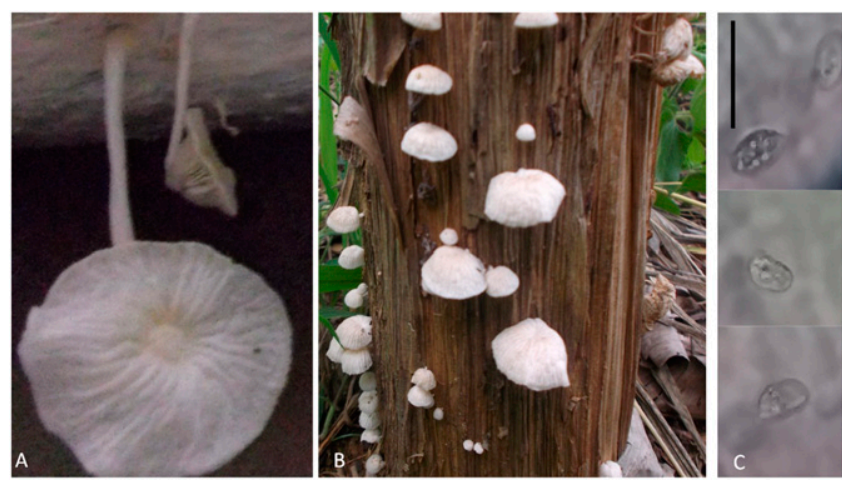

Fig. 4. Fructification of Marasmiellus palmivorus (morphotype E): A, basidiocarps on a cacao branch; B, basidiocarps on pseudo stem of plantain; and C, basidiospores. Scale bar, $10 \mu \mathrm{m}$. white thread blight (morphotype C), dull-white thread blight (morphotype D), and shiny-white thread blight (morphotype E) diseases. Typical leaf blight symptoms were observed on trees affected with these fungal morphotypes and necrotic lesion development on healthy leaves after artificial inoculations confirmed the fungi as pathogenic. In most earlier works concerning TBD of cacao in Ghana, morphological methods alone were used and identified the causal fungus as Marasmiellus scandens (syn: Marasmius scandens or Marasmius byssicola) (Amoako-Attah et al. 2016; Asare-Nyako 1987; Opoku et al. 2007). However, morphological and molecular analyses described here have identified at least four different fungal species: Marasmius crinis-equi, Marasmius tenuissimus, and Marasmiellus palmivorus in addition to Marasmiellus scandens, as responsible for the disease in Ghana. The five TBD-causing morphotypes found on cacao can be distinguished into four species based on their morphological characteristics, which are consistent with ITS, LSU, and $\mathrm{mtSSU}$ gene sequence identifications. Morphological traits important for delimitation of these taxa include the colony color and texture, the absence or presence of rhizomorphs under field growth, their color, and other surface arrangements, in addition to their fruiting structures when present.

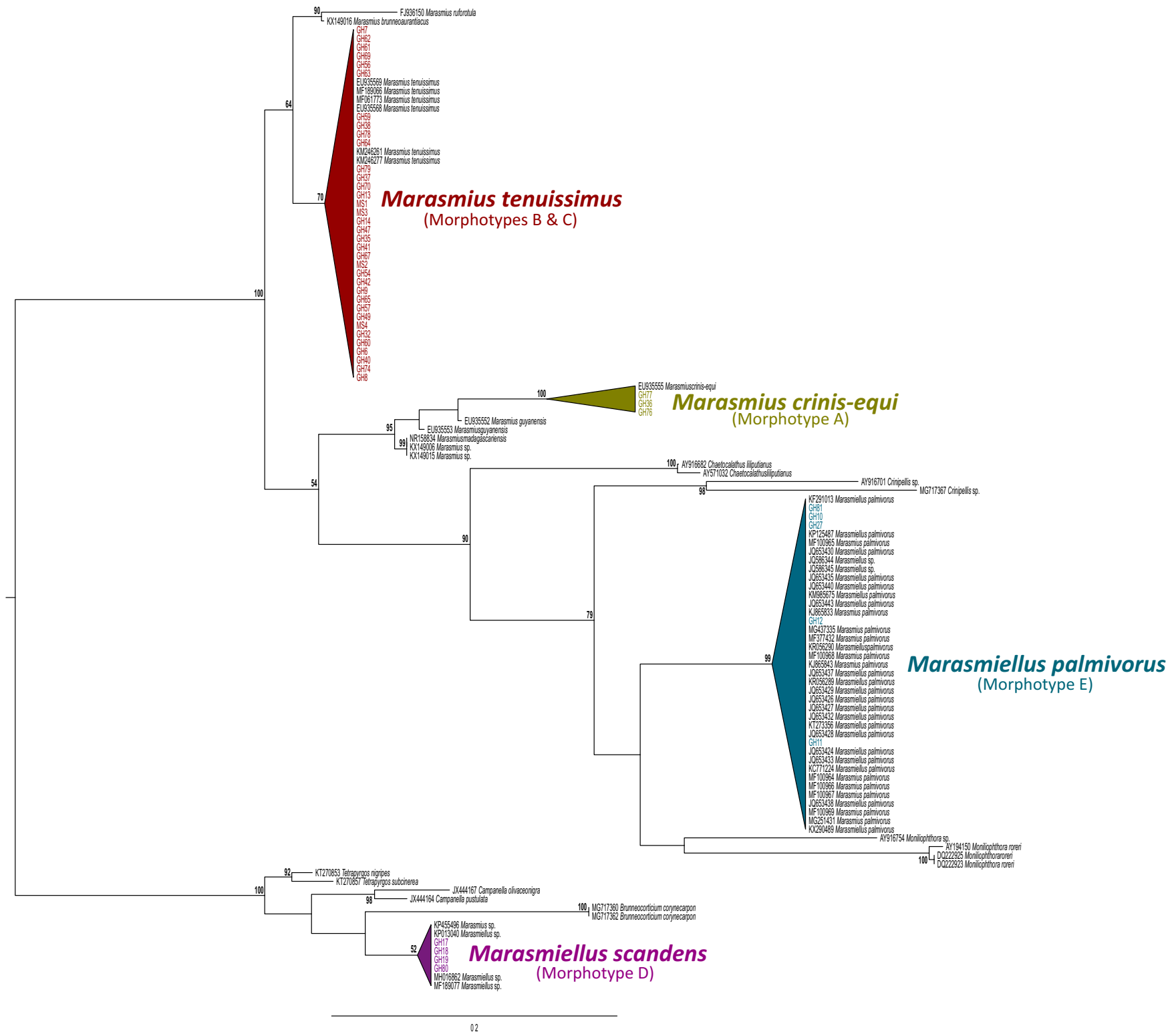

Fig. 5. Maximum likelihood tree of thread blight disease isolates within Marasmiaceae based on internal transcribed spacer sequences. Bootstrap values above $50 \%$ are shown at each supported node. Isolates generated for this study are shown in color/shaded; isolates retrieved from GenBank are shown in black preceded by their GenBank accession number. The tree is midpoint rooted. 
Morphotype A fungal isolates form tough, wiry-black rhizomorphs on branches of cacao tress and were identified as Marasmius crinis-equi. The species epithet and common name for the species were derived from the tough, hair-like stipe (Latin: crinis = hair + equus $=$ horse), and this fungus is referred to as the "horse-hair" mushroom. Samples of morphotype A collected from cacao trees in different geographical locations in Ghana formed a distinct cluster belonging to Marasmius crinis-equi with $100 \%$ bootstrap support and limited genetic variability. Morphologically, the samples examined were similar to Asian (Thailand; Wannathes et al. 2009) and African (Madagascar; Shay 2016) specimens of Marasmius crinis-equi. However, the Madagascan sample was collected from grass species. Marasmius crinis-equi is a well-known aerial-litter-trapping fungus in the tropics and has been confirmed from this study as the cause of "horse-hair" blight disease of cacao (Keane and Putter 1992; Opoku et al. 2007). Besides cacao, it has been reported as pathogenic on rubber (Hevea brasiliensis Mull. Arg.), nutmeg (Myristica fragrans), and tea (Camellia sinensis) (Hu 1984; Pegler 1983). The fungus is recognized by tiny brown to brownish-orange mushrooms having characteristic central papilla within a circular depression (Wannathes et al. 2009). Mushrooms arise directly from the wiryblack rhizomorphs. Su et al. (2011) observed that the rhizomorphs of Marasmius crinis-equi produce volatile substances that cause leaves to defoliate and become trapped in the web of aerial rhizomorphs. Inducing leaves to defoliate and trapping them seems an important adaption for acquiring nutrients. This also partly explains the greater selection pressure for the species to produce rhizomorphs for leaf-litter colonization (trapping) and decomposition in the canopies, rather than the production of fruiting bodies.

Molecular analyses of the ITS, mtSSU, and LSU genes were important in separating the TBD-causing species and distinguishing their different morphotypes. However, this was not the case for morphotypes B and C identified as Marasmius tenuissimus. It was the most common TBD fungus recovered in association with cacao in Ghana and occurred in all geographical locations surveyed (Table 1). It is also reported as the causal agent of TBD of tea in India (Muraleedharan and Baby 2007). Morphologically, the species is identified by the light to brown (or golden) to dark to brown rhizomorphs that grow on both dead and living tree stems and twigs, and also onto the leaves, causing blight symptoms. The morphological characteristics of morphotypes B and C were similar to South American collections of Marasmius tenuissimus (Singer 1976), except that samples of morphotype $\mathrm{C}$ examined here differed slightly by having a paler rhizomorph color. The two morphotypes were grouped into one distinct genetic cluster belonging to Marasmius tenuissimus. It is most likely that morphotypes B and C represent simple genetic color variants or different stages of rhizomorph development (see Fig. 1D). Therefore, the white and the brown thread blight fungi infecting cacao in Ghana are not treated as distinct species. Before any further conclusion is reached on these morphotypes, a morphological assessment of their fruiting bodies should be conducted.

Morphological characteristics of the morphotype D samples examined here were similar to the descriptions of Dennis and Reid (1957) for Marasmiellus scandens. The gene sequences obtained from morphotype D isolates formed a distinct genetic group, Marasmiellus scandens. Initial growth of the fungus on host surfaces was white, later becoming brownish-white. The brownish-white rhizomorphs produced white or whitish to cream mushrooms that differentiated the species from the other closely related thread blight fungi (Marasmius crinis-equi, Marasmius tenuissimus, and Marasmiellus palmivorus) identified on cacao in Ghana. Comparatively, Marasmius crinis-equi had a reddish to orange-brown pileus and Marasmius tenuissimus a light-orange or light-brown to dark-brown pileus (not observed in this study), whereas Marasmiellus palmivorus was white to light-orange (Dennis and Reid 1957; Dutta and Acharya 2018; Singer 1976). This makes pileus color an important speciesdefining feature of TBD fungi on cacao. Additionally, the fungi have an insititious stipe, and the color was of taxonomic significance because it facilitated the species differentiation. The brown stipe of
Marasmiellus scandens distinguishes the taxon from the black stipe of Marasmius crinis-equi, the dark-brown stipe of Marasmius tenuissimus, and the shiny-white stipe with an orange base of Marasmiellus palmivorus. Originally, G. E. Massee described the fungus as Marasmius scandens based on collections of dead cacao leaves from Ghana in 1923 (Antonín 2007). After comparing this fungus with several species of marasmioid thread blight fungi, Dennis and Reid (1957) renamed the fungus as Marasmiellus scandens. The species is commonly referred to as white thread blight fungus of cacao, but this does not represent a true description of the taxon because other whitethread (white rhizomorph-forming) fungi have been identified in this study on cacao. It was considered the main causal agent of TBD of cacao in Ghana, but this requires further investigation. Sampling of TBD-causing fungi for this study tends to support Marasmius tenuissimus as the most common causal agent of the disease on cacao. It is possible that previous publications placed Marasmius tenuissimus isolates under Marasmius scandens or Marasmius byssicola (Asare-Nyako 1987; Opoku et al. 2007), so this information must now be viewed with some discretion. The fungus has also been reported to occur on citrus, tea, and woody trees in tropical and semitropical regions (Lourd and Alves 1987).

Samples of morphotype E occurred on host plants as a mass of cottony mycelium and were collected from three different geographical locations in Ghana (Table 1). Morphological characteristics of the morphotype are closely related to those described by Corner (1996) for Marasmiellus palmivorus. Typically, the fungus grows saprophytically on a number of dying or dead tropical plants and may be carried by wind, rain splash, insects, birds, or human activities to tree canopies where it kills living leaves. Marasmiellus palmivorus is a well-known pathogen of many crops including plantain/ banana (Musa spp.), pineapple (Ananas comosus), ginger (Zingiber spp.), rubber (H. brasiliensis), and giant crepe myrtle (Lagerstroemia speciosa) (Corner 1996; Dutta and Acharya 2018; Farr and Rossman 2017). It has also been identified causing death in nurseries of oil palm (Elaeis guineensis) and coconut (Cocos nucifera) seedlings (Almaliky et al. 2013). Although Sharples described this species in 1936, it is believed that the fungus was responsible for a large loss of coconut and oil palms in Malaysia in 1920 (Pong et al. 2012). This morphotype does not form true rhizomorphs but may appear as thick hyphal aggregations on host surfaces. Mycelial morphology of the fungus was the same in culture and in the field. The fungus is easily distinguished from related species by a characteristic slight depression at the center of the broadly convex to plano-convex or applanate light-orange pileus. Cultures tend to develop pinkish colonies, and this has been consistently useful in recognizing the fungus. Apart from the pinkish coloration, the fungus produces numerous ellipsoidal basidiospores with a short, sharply pointed tip at maturity that is distinctive of the species. Taxon differentiation based on morphological characteristics was well supported by the molecular data from the ITS, mtSSU, and LSU gene regions. The morphotype showed 99\% bootstrap support and formed a distinct cluster with GenBank sequences belonging to Marasmiellus palmivorus. This study is the first report of Marasmiellus palmivorus causing TBD of cacao leaves. The species also caused dieback symptoms on twigs and young branches.

With the exception of Marasmiellus palmivorus, all species identified in this study formed rhizomorphs that were unique in form to the species. Important fruit- and shade-tree crops grown in cacao production systems, such as oil palm, citrus, cola, and plantain/banana, are also host to most of the species. Attention should therefore be directed at educating farmers on the potential risk associated with interplanting these crops in cacao plantations, especially if proper disease management practices are not employed.

\section{Literature Cited}

Aime, M. C., and Phillips-Mora, W. 2005. The causal agents of witches' broom and frosty pod rot of cacao (chocolate, Theobroma cacao) form a new lineage of Marasmiaceae. Mycologia 97:1012-1022.

Almaliky, B. S. A., Kadir, J., Wong, M. Y., and Zainal-Abidin, M. A. 2013. First report of Marasmiellus palmivorus causing post-emergence damping off on coconut seedlings in Malaysia. Plant Dis. 97:143. 
Al-Maliky, B. S. A., Zainal Abidin, M. A., Kadir, J., and Wong, M. Y. 2012. Molecular characterization and phylogenetic analysis of Marasmiellus palmivorus (Sharples) Desjardin using LSU and ITS regions. Retrieved December 10, 2018, from https://blast.ncbi.nlm.nih.gov/Blast.cgi.

Amoako-Attah, I., Akrofi, A. Y., Rashid, B. H., Asamoah, M., and Kumi-Asare, E. 2016. White thread blight disease caused by Marasmiellus scandens (Massee) Dennis \& Reid on cocoa and its control in Ghana. Afr. J. Agric. Res. 11: 5064-5070.

Antonín, V. 2007. Monograph of Marasmius, Gloiocephala, Palaeocephala and Setulipes in Tropical Africa. Fungus Flora of Tropical Africa, Vol. 1. National Botanic Garden, Meise, Belgium.

Asare-Nyako, A. 1987. White thread blight of cocoa. Pages 132-138 in: Proceedings of 1st International Cocoa Pests and Disease Seminar, Accra, Ghana.

Barros, N. O. 1981. Cacao. Manual de Asistencia Tecnica, Vol. 23. Instituto Colombiano Agropecuario, Bogota, Colombia.

Ceresini, P. C., Costa-Souza, E., Zala, M., Furtado, E. L., and Souza, N. L. 2012. Evidence that the Ceratobasidium-like white-thread blight and black rot fungal pathogens from persimmon and tea crops in the Brazilian Atlantic Forest agroecosystem are two distinct phylospecies. Genet. Mol. Biol. 35:480-497.

César, E., Bandala, V. M., Montoya, L., and Ramos, A. 2018. A new Gymnopus species with rhizomorphs and its record as nesting material by birds (Tyrannideae) in the subtropical cloud forest from eastern Mexico. MycoKeys 42:21-34

Corner, E. J. H. 1996. The agaric genera Marasmius, Chaetocalathus, Crinipellis, Heimiomyces, Resupinatus, Xerula, and Xerulina in Malesia. Beih. Nova Hedwigia. 111:1-141.

David, S. 2005. Learning About Sustainable Cocoa Production: A Guide for Participatory Farmer Training. 1. Integrated Crop and Pest Management. Sustainable Tree Crop Program. IITA, Yaoundé, Cameroon.

Dechassa, N. 2019. Occurrence, distribution, biology and management of coffee thread blight (Corticium koleroga (Cke) Hoehnel): A review. J. Environ. Earth Sci. 9(2).

Dennis, R. W. G., and Reid, D. A. 1957. Some marasmoid fungi allegedly parasitic on leaves and twigs in the tropics. Kew Bull. 12:287-292.

Dutta, A. K., and Acharya, K. 2018. A new host for the parasitic macrofungus Marasmius palmivorus Sharples (Marasmiaceae). Curr. Sci. 114:1400-1407.

Edgar, R. C. 2004. MUSCLE: Multiple sequence alignment with high accuracy and high throughput. Nucleic Acids Res. 32:1792-1797.

Farr, D. F., and Rossman, A. Y. 2017. Fungal Databases, U. S. National Fungus Collections, ARS, USDA. Retrieved April 27, 2017, from https://nt.arsgrin.gov/fungaldatabases/.

Gasparotto, L., and Silva, S. E. L. 1999. New hosts of Pellicularia koleroga in the state of Amazonas, Brazil. Fitopatol. Bras. 24:469.

Hedger, J. 1990. Fungi in the tropical forest canopy. Mycologist 4:200-202.

Hu, C. C. 1984 . Horse-hair blight, new disease of tea bush caused by Marasmius equicrinis Mull in Taiwan. Taiwan Tea Res Bull 3:1-4.

Humber, R. A. 2005. Fungal Identification. USDA-ARS Plant Protection Research Unit, U.S. Plant, Soil, and Nutrition Laboratory, Ithaca, NY.

Katoh, K., and Standley, D. M. 2013. MAFFT Multiple Sequence Alignment Software Version 7: Improvements in performance and usability. Mol. Biol. Evol. 30:772-780.

Keane, P. J., and Putter, C. A. J., eds. 1992. Cocoa Pest and Disease Management in South East Asia and Australia. FAO Plant Production and Protection Paper 112. FAO, Rome, Italy.

Kirk, P. M., Cannon, P. F., Minter, D. W., and Stalpers, J. A. 2008. Page 402 in: Dictionary of the Fungi, 10th Ed. CAB International, Wallingford, U.K.

Koch, R. A., Lodge, D. J., Sourell, S., Nakasone, K., McCoy, A. G., and Aime, M. C. 2018. Tying up loose threads: Revised taxonomy and phylogeny of an avian-dispersed neotropical rhizomorph-forming fungus. Mycol. Prog. 17: 989-998.

Lekete, E. 2012. Morphological characterisation and in vitro management of thread blight pathogens of cocoa (Theobroma cacao L.). Master's thesis. University of Science and Technology, Kumasi, Ghana.

Lourd, M., and Alves, B. 1987. Lista de hospedeiro e etiologia da queima-do-fio das plantas frutı'feras na região Amazônica. Fitopatol. Bras. 12:88-89.

Miller, M. A., Pfeiffer, W., and Schwartz, T. 2010. Creating the CIPRES Science Gateway for inference of large phylogenetic trees. Proceedings of the Gateway Computing Environments Workshop (GCE), New Orleans, LA.
Muraleedharan, N., and Baby, U. I. 2007. Tea diseases: Ecology and control. Pages 668-671 in: Encyclopedia of Pest Management, Vol. II. D. Pimentel, ed. CRC Press, Boca Raton, FL.

Nelson, S. C., and Javier, B. 2001. Report document on diagnosis of banana, yam and other diseases in Pohopei. No. 20 (Second Update, August 2014). College of Micronesia, Kolonia, Pohnpei, Federated States of Micronesia.

Opoku, I. Y., Assuah, M. K., and Domfeh, O. 2007. Manual for the Identification and Control of Diseases of Cocoa. CRIG Technical Bulletin No.16. Cocoa Research Institute of Ghana, Akim-Tafo, Ghana.

Pegler, D. N. 1983. Agarics flora of Lesser Antilles. Kew Bull. Add. Ser. 9: 195-232.

Pong, V. M., Zainal Abidin, M. A., Al-maliky, B. S. A., Kadir, J., and Wong, M. Y., 2012. Isolation, fruiting and pathogenicity of Marasmiellus palmivorus (Sharples) Desjardin (comb. prov.) in oil palm plantations in West Malaysia. Pertanika J. Trop. Agric. Sci. 35:37-48.

Roberts, P. 1999. Ceratobasidium noxium (Donk). Page 246 in: RhizoctoniaForming Fungi: A Taxonomic Guide. P. Roberts, ed. Royal Botanic Gardens, Kew, U.K.

Schoch, C. L., Seifert, K. A., Huhndorf, S., Robert, V., Spouge, J. L., Levesque, C. A., Chen, W., Bolchacova, E., Voigt, K., Crous, P. W., Miller, A. N., Wingfield, M. J., Okada, G., Suzuki, M., Hambleton, S., Otte, J., Schmitt, I., Boonyuen, N., Jones, E. B. G., Suetrong, S., Tretter, E., White, M. M., Hognabba, F., Stenroos, S., Hagen, F., Eberhardt, U., Quaedvlieg, W., Boekhout, T., Damm, U., De-Hoog, S., Groenewald, J., Z., Groenewald, M., Walther, G., Duong, V., Schubler, A., Qing, C., Yang, Z. L., Bogale, M., Untereiner, W. A., Maganti, H., Xu, J. P., Leavitt, S. D., Lumbsch, H. T., Hansen, K., Olariaga, I., Duong, T. A., De Beer, Z. W., Nilsson, R. H., Cardinali, G., Burgaz, A. R., Crespo, A., Del-Prado, R., Divakar, P. K., Ruibal, C., Sotome, K., Huhtinen, S., Fliegerova, K., Douglas, B., Griffith, G. W., An, K. D., Johnston, P. R., Park, D., Weir, B. S., Blackwell, M. Urbina, H., Aime, M. C., Heller, G., McTaggart, A. R., Hyde, K. D., Kurtzman, C. P., Luangsa-Ard, J. J., Mongkolsamrit, S., Hosaka, K., Tedersoo, L., Bergeron, M. J., Hamelin, R. C., Vialle, A., Okane, I. Liimatainen, K., Niskanen, T., Dieguez-Uribeondo, J., Duenas, M., Garcia, M. A., Martin, M. P., Pino-Bodas, R., Sarmiento-Ramirez, J. M., Telleria, M. T., Zamora, J. C., Coppins, B. J., Harrold, P., Hollingsworth, P., Kelly, L. J., Yahr, R., Griffiths, K., May, T., Stefani, F. O. P., Yurkov, A., Begerow, D., Bai, F. Y., Cai, L., Guo, L. D., Raja, H. A., Redecker, D. Stockinger, H., Shearer, C., Nagy, L. G., Nyilasi, I., Papp, T., Petkovits, T., Vagvolgyi, C., Koljalg, U., Barreto, R., Buyck. B., Chaverri, P., Dentinger, B., Elshahed, M. S., Ge, Z. W., Gryzenhout, M., Ho, H. M., Hofstetter, V., Hong, S. B., Houbraken, J., Hughes, K., James, T., Johnson, E., Kirk, P., Kovacs, G. M., Landvik, S., Liggenstoffer, A. S., Lombard, L., Meyer, W., Moncalvo, J. M., Rintoul, T., Suh, S. O., Tanaka, K., Vu, D., Wang, Y., Weiss, M., Zhang, N., Zhuang, W. Y., and Schindel, D. 2012. The internal transcribed spacer as a universal DNA barcode marker for Fungi. Proc. Natl. Acad. Sci. U.S.A. 109:6241-6246.

Shay, J. E. 2016. Biodiversity and phylogeny of Marasmius from Madagascar Master's thesis. San Francisco State University, San Francisco, CA.

Singer, R. 1976. Marasmiaceae (Basidiomycetes-Tricholomataceae). Fl. Neotropica $17: 1-348$

Stamatakis, A. 2014. RAxML version 8: A tool for phylogenetic analysis and postanalysis of large phylogenies. Bioinformatics 30:1312-1313.

Su, H. J., Thseng, F. M., Chen, J. S., and Ko, W.-H. 2011. Production of volatile substances by rhizomorphs of Marasmius crinis-equi and its significance in nature. Fungal Divers. 49:199-202.

Vantamuri, A. B., and Kaliwal, B. B. 2015. Production and optimization of laccase by Marasmius sp. BBKAV79 in submerged fermentation. Int. J. Curr. Res. 7 : 18308-18314.

Wannathes, N., Desjardin, D. E., Hyde, K. D., Perry, B. A., and Lumyong, S. 2009 A monograph of Marasmius (Basidiomycota) from northern Thailand based on morphological and molecular (ITS sequences) data. Fungal Divers. 37: 209-306.

White, T. J., Bruns, T., Lee, S., and Taylor, J. 1990. Amplification and direct sequencing of fungal ribosomal RNA genes for phylogenetics. Pages 315-322 in: PCR Protocols: A Guide to Methods and Applications. M. A. Innis, D. H. Gelfand, J. J. Sninsky, and T. J. White, eds. Academic Press, London, U.K. 